\title{
Pengaruh Rasio Kulit Buah Kopi dan Air Serta Konsentrasi Gula terhadap Mutu Sirup Kulit Buah Kopi
}

\author{
(The Effect of the Ratio of Coffee Fruit Skin and Water Rind and Sugar Consentration to the \\ Quality of Coffee Fruit Skin Syrup)
}

\author{
Desi Laila Sari ${ }^{1}$, Eva Murlida ${ }^{1}$, Yuliani Aisyah ${ }^{1 *}$ \\ ${ }^{1}$ Program Studi Teknologi Hasil Pertanian, Fakultas Pertanian, Universitas Syiah Kuala
}

\begin{abstract}
Abstrak. Salah satu permasalahan utama dan terbesar dalam proses pengolahan buah kopi menjadi biji adalah penanganan limbah buah kopi baik limbah padat (kulit kopi) maupun limbah cair (air cucian kopi dan lendir kulit buah kopi). Kulit buah kopi mengandung air, serta, gula, tanin, mineral, lemak, senyawa volatil dan senyawa lainnya. Penelitian ini dilakukan untuk mengetahui pengaruh rasio kulit buah kopi dan air serta konsentrasi gula yang digunakan terhadap mutu sirup kulit buah kopi yang dihasilkan. Penelitian ini menggunakan Rancangan Acak Lengkap (RAL) dengan pola Faktorial yang terdiri atas dua faktor. Faktor pertama adalah rasio kulit kopi dan air (R), yang terdiri atas 3 taraf 1:1 (R1), 1:1,5 (R2) dan 1:2 (R3). Faktor kedua adalah konsentrasi gula (K), yang terdiri atas 3 taraf yaitu 90\% (K1), 100\% (K2) dan 110\% (K3). Kombinasi perlakuan adalah 3 x $3=9$. Setiap perlakuan dilakukan ulangan sebanyak 3 kali sehingga diperoleh 27 satuan percobaan. Analisis yang dilakukan terhadap sirup kulit buah kopi meliputi analisis viskositas, pH, total asam, organoleptik (hedonik) dan aktivitas antioksidan. Hasil penelitian menunjukkan bahwa rasio kulit buah kopi dan air berpengaruh nyata terhadap aroma sirup kulit buah kopi. Adapun konsentrasi gula berpengaruh sangat nyata terhadap $\mathrm{pH}$ sirup kulit buah kopi. Interaksi antara rasio kulit buah kopi dan air serta konsentrasi gula berpengaruh sangat nyata terhadap total asam dan warna sirup kulit buah kopi. Sirup kulit buah kopi yang dihasilkan memiliki viskositas berkisar dari 5,50 cP-82,50 cP; pH berkisar dari 1-5,6 ; total asam berkisar 0,16\%-0,45\%.; hedonik warna berkisar dari 2,79-3,37 (tidak suka - netral); hedonik aroma berkisar dari 2,44-3,32 (tidak suka - netral); hedonik rasa berkisar dari 3,16-3,63 (netral); hedonik kekentalan berkisar dari 2,68 - 3,72 (tidak suka - netral) dan aktivitas antioksidan berkisar dari 0,30-0,32\%.
\end{abstract}

Kata kunci: Buah kopi, kulit kopi, air, gula, sirup.

Abstract. One of the main and biggest problems in processing coffee fruit into seeds is handling coffee fruit waste both solid waste (coffee skin) and liquid waste (coffee washing water and coffee fruit skin mucus). The skin of coffee fruit contains water, as well as sugar, tannins, minerals, fats, volatile compounds and other compounds. This study was conducted to determine the effect of the ratio of coffee and water rind and the concentration of sugar used to the quality of coffee fruit skin syrup produced. This study used a Completely Randomized Design (CRD) with a factorial pattern consisting of two factors. The first factor was the ratio of coffee skin and water (R), which consists of 3 levels (1: $1(\mathrm{R} 1), 1: 1.5(\mathrm{R} 2)$ and 1: $2(\mathrm{R} 3))$. The second factor was the concentration of sugar (K), which consists of 3 levels (90\% (K1), 100\% (K2) and 110\% (K3)). The treatment combination was $3 \times 3=9$. Each treatment was repeated 3 times to obtain 27 experimental units. Analysis carried out on coffee fruit skin syrup included analysis of viscosity, $\mathrm{pH}$, total acid, organoleptic (hedonic), and antioxidant activity. The results showed that the ratio of coffee and water rind significantly affected the aroma of coffee fruit skin syrup. The concentration of sugar had a very significant effect on the $\mathrm{pH}$ of coffee fruit skin syrup. The interaction between the ratio of coffee fruit skin and water and sugar concentration had a very significant effect on the total acidity and color of coffee fruit skin syrup. The resulting coffee fruit skin syrup has viscosity ranging from $5.50 \mathrm{cP}-82.50 \mathrm{cP} ; \mathrm{pH}$ ranges from $1-5.6$; total acid ranged from $0.16 \%-0.45 \%$; hedonic colors range from 2.79-3.37 (dislike - neutral); hedonic scents range from 2.44-3.32 (dislike - neutral); hedonic taste ranges from 3.16-3.63 (neutral); hedonic viscosity ranges from 2.68 - 3.72 (dislike - neutral) and antioxidant activity ranges from $0.30-0.32 \%$.

Keywords: Coffee fruit, coffee skin, water, sugar, syrup.

Corresponding author: yuliani.aisyah@unsyiah.ac.id

JIM Pertanian - THP, Vol. 4, No. 2, Mei 2019: 280-289 


\section{PENDAHULUAN}

Kopi merupakan salah satu tanaman hasil perkebunan yang biasa dikonsumsi dalam bentuk minuman. Saat ini kopi sudah menjadi bagian dari kebiasaan dan budaya masyarakat baik di pedesaan maupun perkotaan. Ada banyak jenis kopi yang beredar di pasaran, akan tetapi yang umum adalah kopi Arabika, Robusta dan Liberica. Kopi Arabika, Robusta dan Liberica berbeda secara fisik, iklim dan ketinggian tempat, sifat kimia dan penyajiannnya yang akan berpengaruh terhadap citarasanya (Tarigan, 2015). Kopi jenis Liberica adalah yang termahal diantara ketiga varietas tersebut. Oleh karena itu Liberica termasuk tanaman langka karena produktifitasnya tidak terlalu tinggi.

Salah satu permasalahan utama dan terbesar dalam proses pengolahan buah kopi menjadi biji adalah penanganan limbah buah kopi baik limbah padat (kulit kopi) maupun limbah cair (air cucian kopi dan lendir kulit buah kopi). Pada proses pengolahan kopi dihasilkan limbah padat yang sangat besar yakni 40-45\%. Hal ini menunjukkan bahwa proses pengolahan kopi menghasilkan limbah padat yang besar. Kulit buah kopi masih mengandung kadar air sebanyak $75-80 \%$, sehingga mudah rusak apabila tidak diolah sesegera mungkin (Simanihuruk dan Sirait, 2010).

Kulit kopi mengandung komponen nutrisi dan senyawa lain yang bisa diolah menjadi produk yang bernilai tambah (Widyotomo, 2012). Selama ini, pemanfaatan kulit buah kopi hanya terbatas sebagai pakan ternak dan pupuk. Oleh karena itu, diperlukan teknologi pengolahan lain agar kulit buah kopi menjadi lebih bernilai dan bermanfaat. Salah satu caranya yaitu dengan memanfaatkan kulit buah kopi sebagai bahan dalam pembuatan sirup. Sirup adalah salah satu produk jenis minuman yang dapat diperoleh dengan cara mencampurkan gula dengan sari buah yang diencerkan dengan air dengan kandungan gula minimal 65\% (Susanti, 2016). Prinsip pembuatan sirup adalah dengan pasteurisasi. Pasteurisasi adalah proses pemanasan dengan menggunakan suhu di bawah $100^{\circ} \mathrm{C}$ untuk menginaktifkan mikroba berbahaya agar memiliki daya tahan lebih lama.

Perbedaan volume rasio kulit buah kopi : air merupakan salah satu faktor yang perlu diamati karena diduga dapat mempengaruhi rasa sirup yang dihasilkan. Pada penelitian ini rasio kulit kopi dan air yang digunakan adalah 1:1, 1:1,5 dan 1:2. Selain itu jumlah gula yang ditambahkan juga merupakan faktor penting dalam menentukan kualitas organoleptik sirup yang dihasilkan. Oleh karena itu pada penelitian ini juga diamati beberapa taraf konsentrasi gula yaitu 90\%, 100\% dan $110 \%$. Bila jumlah ekstrak kulit kopi yang digunakan terlalu banyak dan gula terlalu sedikit dapat menghasilkan sirup dengan rasa yang getir di lidah. Pada proses pembuatan sirup minimal kadar gula sirup adalah 65\% (SNI 3544 : 2013).

Maka dari itu, pada penelitian ini dikaji pengaruh rasio kulit buah kopi dan air serta konsentrasi gula terhadap mutu sirup kulit buah kopi.

\section{METODE PENELITIAN}

Penelitian ini dilaksanakan pada bulan Agustus - September 2018. Penelitian ini dilakukan di Laboratorium Rekayasa Pangan dan Industri, Laboratorium Analisis Pangan dan Hasil Pertanian, dan Laboratorium Evaluasi Sensori Jurusan Teknologi Hasil Pertanian, Fakultas Pertanian, Universitas Syiah kuala.

\section{Bahan dan Alat}

Bahan utama yang digunakan pada penelitian adalah kulit buah kopi yang berwarna merah. Sampel tersebut diperoleh dari perkebunan desa Bius Utama, Kec. Silih Nara, Kab. 
Aceh Tengah. Bahan kimia yang digunakan yaitu gula, CMC 0,3\% (Carboxy Methyl Cellulose), aquades dan bahan penunjang analisis seperti larutan DPPH. Alat yang digunakan pada penelitian ini adalah timbangan, beaker glass $500 \mathrm{ml}$, pisau, panci, sendok pengaduk, blender, botol kaca, kompor, wadah dan kain saring.

\section{Rancangan Penelitian}

Penelitian ini dilakukan dengan mengggunakan Rancangan Acak Lengkap (RAL) Faktorial yang terdiri atas dua faktor. Faktor pertama adalah rasio kulit kopi dan air (R), yang terdiri atas 3 taraf 1:1 (R1), 1:1,5 (R2) dan 1:2 (R3). Faktor kedua adalah konsentrasi gula (K), yang terdiri atas 3 taraf yaitu 90\% (K1), 100\% (K2) dan 110\% (K3). Kombinasi perlakuan adalah 3 x $3=9$. Setiap perlakuan dilakukan ulangan sebanyak 3 kali sehingga diperoleh 27 satuan percobaan.

\section{Prosedur Penelitian}

Buah kopi yang masih utuh dengan kulitnya disortasi dan dicuci serta dikupas kulitnya. Kemudian kulit buah kopi diblender lalu ditambahkan air sesuai perlakuan yaitu 1:1, 1:1,5 dan 1:2 dan disaring hingga tiga kali penyaringan. Ekstrak kulit buah kopi ditambahkan gula sesuai perlakuan yaitu 90\%, 100\% dan 110\% (dari jumlah bahan) serta CMC 0,3\% dari volume bahan dan dipanaskan selama 7 menit. Kemudian dilakukan penyaringan dan dimasukkan ke dalam botol kaca yang sudah disterilisasi sebelumnya (volume botol $600 \mathrm{ml}$ ). Dilakukan analisis terhadap sirup kulit buah kopi.

\section{Analisis Viskositas (Zulkarnain dkk, 2013).}

Sebanyak $100 \mathrm{ml}$ larutan dimasukkan ke dalam wadah yang berbentuk tabung dan dipasang spindle pada alat. Spindle harus terendam ke dalam bahan dan wadah. Kemudian alat viskometer dinyalakan dan rotor berputar pada kecepatan $60 \mathrm{rpm}$. Lalu diamati jarum penunjuk pada viskometer yang mengarah ke angka skala viskositas. Kemudian dicatat dan dikalikan faktor 100 .

\section{Analisis pH (Bawinto dkk, 2015).}

Sampel diambil sebanyak $10 \mathrm{ml}$ dan dilarutkan dengan akuades $20 \mathrm{ml}$. Kemudian dituang kedalam beaker glass ukuran $10 \mathrm{ml}$ dan diukur $\mathrm{pH}$ nya dengan menggunakan $\mathrm{pH}$ meter. $\mathrm{pH} 7$ harus tertera pada jarum penunjuk sebelum $\mathrm{pH}$ meter digunakan. Setelah itu jarum ditempatkan pada cairan dalam beaker glass. Besarnya $\mathrm{pH}$ dapat dibaca setelah jarum penunjuk $\mathrm{pH}$ dalam keadaan konstan kedudukannya.

\section{Analisis Total Asam}

Prinsip analisis total asam ialah keasaman diukur dengan metode titrasi. Sebanyak 10 ml sampel ditetesi dengan 2-3 tetes indikator fenolftalein dan kemudian dititrasi dengan larutan $\mathrm{NaOH} 0,1 \mathrm{~N}$ hingga sesuai dengan larutan standar yakni berwarna merah muda dan stabil.

Total Asam $(\%)=(\mathrm{a} \times 0,009 \times 100 / \mathrm{b})$

Keterangan :

$$
\begin{aligned}
& \mathrm{a}=\mathrm{ml} \mathrm{NaOH} 0,1 \mathrm{~N} \text { x N NaOH } 0,1 \mathrm{~N} \\
& \mathrm{~b}=\text { berat sampel }(\mathrm{g})
\end{aligned}
$$




\section{Analisis Organoleptik (Tarwendah, 2017)}

Uji organoleptik yang dilakukan yakni uji Hedonik. Uji hedonik adalah salah satu metode pengujian sensori yang digunakan untuk mengetahui besarnya perbedaan kualitas antara beberapa produk yang sejenis dan memberikan penilaian maupun skor terhadap produk yang memiliki sifat tertentu serta mengetahui tingkat kesukaan panelis terhadap produk tersebut. Uji hedonik biasa disebut dengan uji tingkat kesukaan meliputi sangat suka, suka, agak tidak suka, tidak suka, sangat ttidak suka dan lain-lain. Prinsipuji hedonik adalah panelis diminta untuk memberikan tanggapan pribadinya tentang tingkat kesukaan atau ketidaksukaannya pada suatu produkn dengan skala hedonik. Lembar kuisioner yang akan digunakan dalam uji hedonik sirup kulit buah kopi dapat dilihat pada Lampiran 3.

\section{Analisis Antioksidan Metode DPPH (Hanani, 2005)}

Larutan DPPH $1 \mathrm{mM}$ (dalam metanol) sebanyak $1 \mathrm{ml}$ dimasukkan ke dalam tabung reaksi. Kulit buah kopi dilarutkan dalam metanol lalu dimasukkan ke dalam tabung reaksi hingga volume larutan tepat $5 \mathrm{ml}$. Larutan tersebut didiamkan selama 30 menit dan diukur absorbansinya pada 515,5 $\mathrm{nm}$. Larutan troloks dengan berbagai konsentrasi digunakan untuk membuat kurva kalibrasi. Kapasitas antioksidan dinyatakan dalam $\mu$ mol troloks/g serbuk kering.

$$
\% \text { inhibisi }=\left(\frac{\text { absorbansi blanko-absorbansi sampel }}{\text { absorbansi blanko }}\right) \times 100
$$

\section{HASIL DAN PEMBAHASAN}

\section{Viskositas}

Pada penelitian ini, viskositas kopi yang dihasilkan berkisar dari 5,50 cP-82,50 cP, dengan rerata umum $26,76 \mathrm{cP}$. Analisis sidik ragam menunjukkan bahwa rasio kulit kopi dan air (R), konsentrasi gula $(\mathrm{K})$ dan interaksi antara kopi dan air serta konsentrasi gula (RK) berpengaruh tidak nyata $(\mathrm{P}<0,05)$ terhadap viskositas sirup kulit buah kopi. Gula merupakan salah satu faktor yang mempengaruhi viskositas sirup. Semakin banyak gula yang diberikan maka semakin tinggi viskositas sirup tersebut. Gula yang ditambahkan pada proses pemanasan akan mengikat air bebas dan larut dalam air dan membentuk larutan kental (Bastanta dkk, 2017), namun didalam penelitian ini konsentrasi gula yang ditambahkan belum menunjukkan perbedan yang nyata terhadap nilai viskositas dari sirup buah kopi.

pH

Pada penelitian ini, $\mathrm{pH}$ sirup kulit buah kopi yang dihasilkan berkisar dari 1-5,6 dengan rerata umum 4,40. Analisis sidik ragam menunjukkan bahwa konsentrasi gula (K) berpengaruh nyata $(\mathrm{P}>0,05)$ sedangkan rasio kulit kopi dan air $(\mathrm{R})$ serta interaksi antara rasio kulit kopi dan air serta konsentrasi gula $(\mathrm{RK})$ berpengaruh tidak nyata $(\mathrm{P}<0,05)$ terhadap $\mathrm{pH}$ sirup kulit buah kopi. Pengaruh konsentrasi gula terhadap $\mathrm{pH}$ sirup kulit buah kopi dapat dilihat pada Gambar 1.

Berdasarkan uji lanjut DMRT pada Gambar 1, dapat dilihat bahwa pH dari sirup kulit buah kopi dengan konsentrasi penambahan gula yang berbeda adalah sama atau tidak berbeda nyata, yang ditunjukkan dengan huruf notasi yang sama. Hal ini menunjukkan bahwa konsentrasi gula yang ditambahkan belum menunjukkan perbedaan yang nyata terhadap nilai 
$\mathrm{pH}$ dari sirup buah kopi. Nilai $\mathrm{pH}$ didalam penelitian ini lebih rendah dibandingkan dengan penelitian Fitriani dan Sribudiani (2009) tentang pembuatan sirup nanas yang menggunakan bahan baku kulit nanas dan daging buah nanas, dengan nilai $\mathrm{pH}$ 4,27-5,20. Sedangkan beberapa penelitian menunjukkan bahwa $\mathrm{pH}$ sirup jambu merah 4,42 - 4,51 (Sihombing, 2013), pH sirup belimbing wuluh 4,14-4,32 (Fitri dkk., 2011). Asam-asam organik yang terkandung didalam buah diduga dapat mempengaruhi $\mathrm{pH}$ dari sirup.

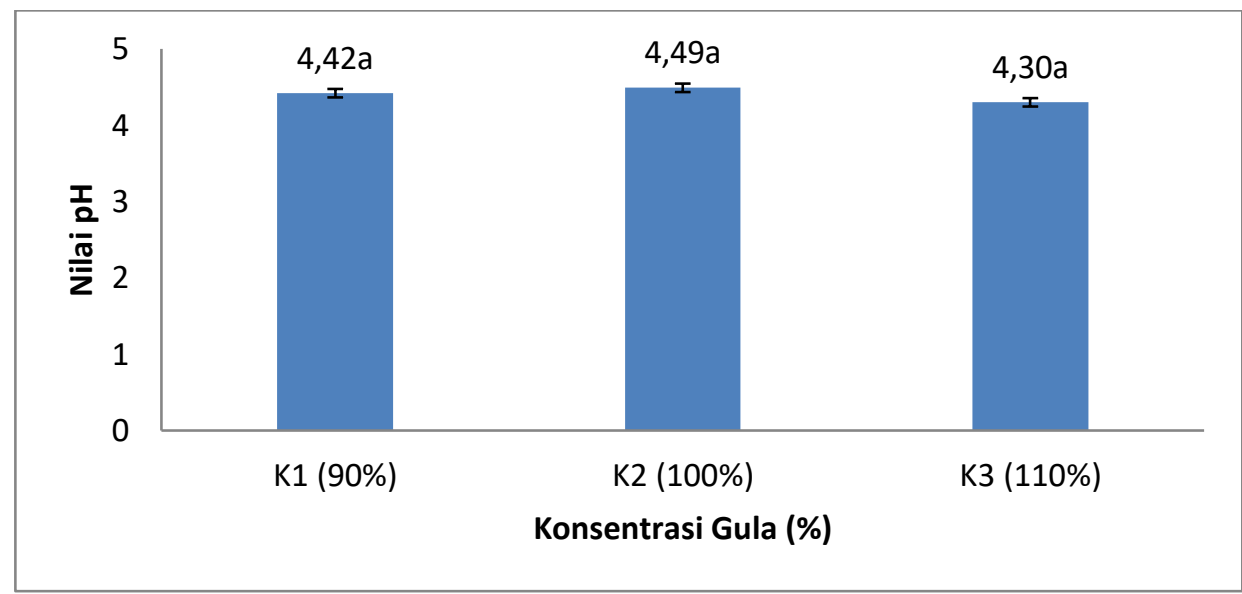

Gambar 1. Pengaruh konsentrasi gula terhadap pH sirup kulit buah kopi $\left(\mathrm{DMRT}_{0,01}\right.$ taraf $1=1,78 ; \operatorname{taraf} 2=1,44$ dan $\mathrm{KK}=26,96 \%$ ). Nilai yang diikuti huruf yang sama menunjukkan perbedaan yang tidak nyata.

\section{Total Asam}

Dari hasil penelitian diperoleh nilai total asam sirup kulit buah kopi berkisar antara 0,16\%-0,45\%. Hasil sidik ragam menunjukkan bahwa rasio kulit buah kopi dan air (R) serta konsentrasi gula $(\mathrm{K})$ tidak berpengaruh nyata $(\mathrm{P}<0,05)$ terhadap nilai total asam sirup kulit buah kopi sedangkan interaksi antara rasio kulit buah kopi dan air serta konsentrasi gula (RK) berpengaruh nyata $(\mathrm{P}>0,05)$ terhadap nilai total asam sirup kulit buah kopi. Pengaruh interaksi rasio kulit buah kopi dan air serta konsentrasi gula terhadap nilai total asam sirup kulit buah kopi dapat dilihat pada Gambar 2.

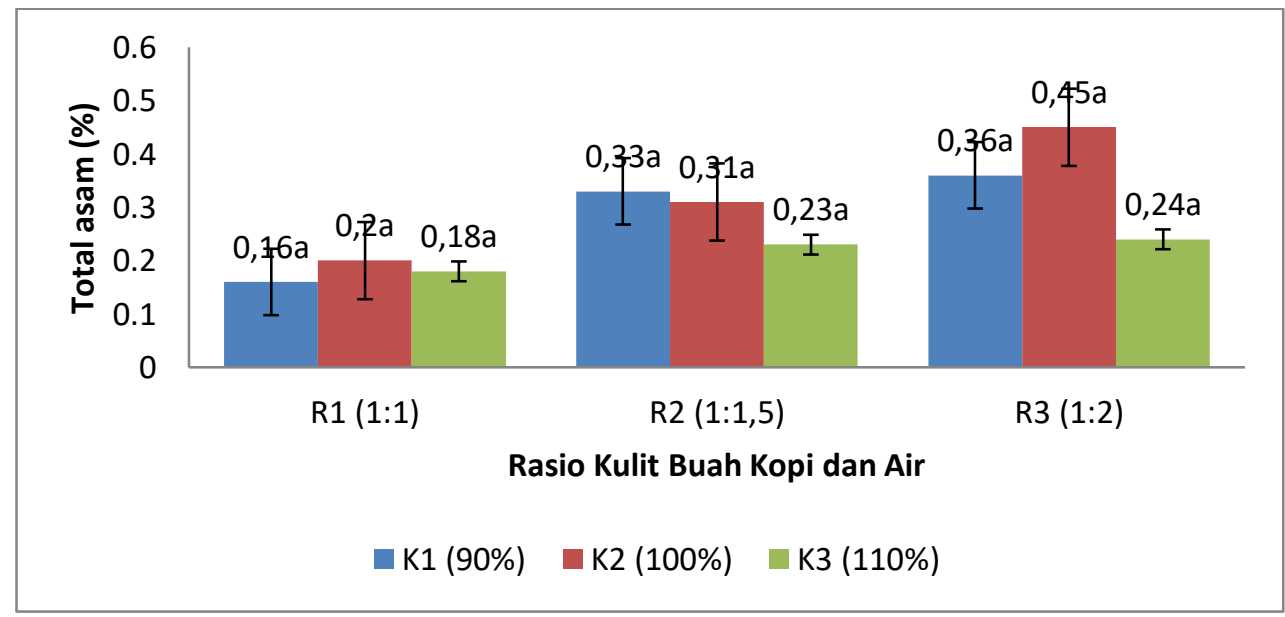

Gambar 2. Pengaruh interaksi rasio kulit buah kopi dan air serta konsentrasi gula terhadap total asam sirup kulit buah kopi $\left(\mathrm{DMRT}_{0,01} \operatorname{taraf} 1=15,85 ; \operatorname{taraf} 2=11,58 ; \operatorname{taraf} 3=9,83 ; \operatorname{taraf} 4=8,86 ; \operatorname{taraf} 5=8,25\right.$ ; taraf $6=7,80$; taraf $77=7,49$; taraf $8=7,23$ dan taraf $9=7,02$. KK $=2051,22$ ). Nilai yang diikuti huruf yang sama menunjukkan perbedaan yang tidak nyata. 
Berdasarkan uji lanjut DMRT pada Gambar 2, dapat dilihat bahwa total asam dari sirup kulit buah kopi dengan perlakuan interaksi rasio kulit buah kopi dan konsentrasi gula yang berbeda memiliki nilai yang sama atau tidak berbeda nyata, yang ditunjukkan dengan huruf notasi yang sama. Hal ini menunjukkan bahwa interaksi perlakuan rasio kulit buah kopi dan air, serta konsentrasi gula yang ditambahkan belum menunjukkan perbedaan yang nyata terhadap nilai $\mathrm{pH}$ dari sirup buah kopi. Menurut Bastanta dkk (2017), perbandingan antara sari sirsak dan sari bit memberikan pengaruh sangat nyata $(\mathrm{P}>0,01)$ terhadap total asam sirup yang dihasilkan. Semakin banyak jumlah sari sirsak dan sari bit yang digunakan maka total asam yang dihasilkan akan semakin meningkat. Peningkatan konsentrasi sari sirsak dan sari bit akan meningkatkan kandungan asam sitrat sebagai asam organic yang dominan sehingga menambah total asam pada sirup tersebut.

\section{Analisis Organoleptik (Hedonik)}

\section{Warna}

Dari hasil penelitian diperoleh nilai organoleptik warna dari sirup kulit kopi yaitu berkisar antara 2,79-3,37 (tidak suka - netral). Hasil sidik ragam menunjukkan bahwa rasio kulit buah kopi dan air $(\mathrm{R})$ serta konsentrasi gula $(\mathrm{K})$ tidak berpengaruh nyata $(\mathrm{P}<0,05)$ terhadap warna sirup kulit kopi. Sedangkan interaksi antara konsentrasi gula (K) dan rasio kulit buah kopi dan air $(\mathrm{R})$ berpengaruh nyata $(\mathrm{P}>0,05)$ terhadap sirup kulit kopi. Pengaruh interaksi rasio kulit kopi dan air serta konsentrasi gula (RK) terhadap warna sirup kulit buah kopi dapat dilihat pada Gambar 3.

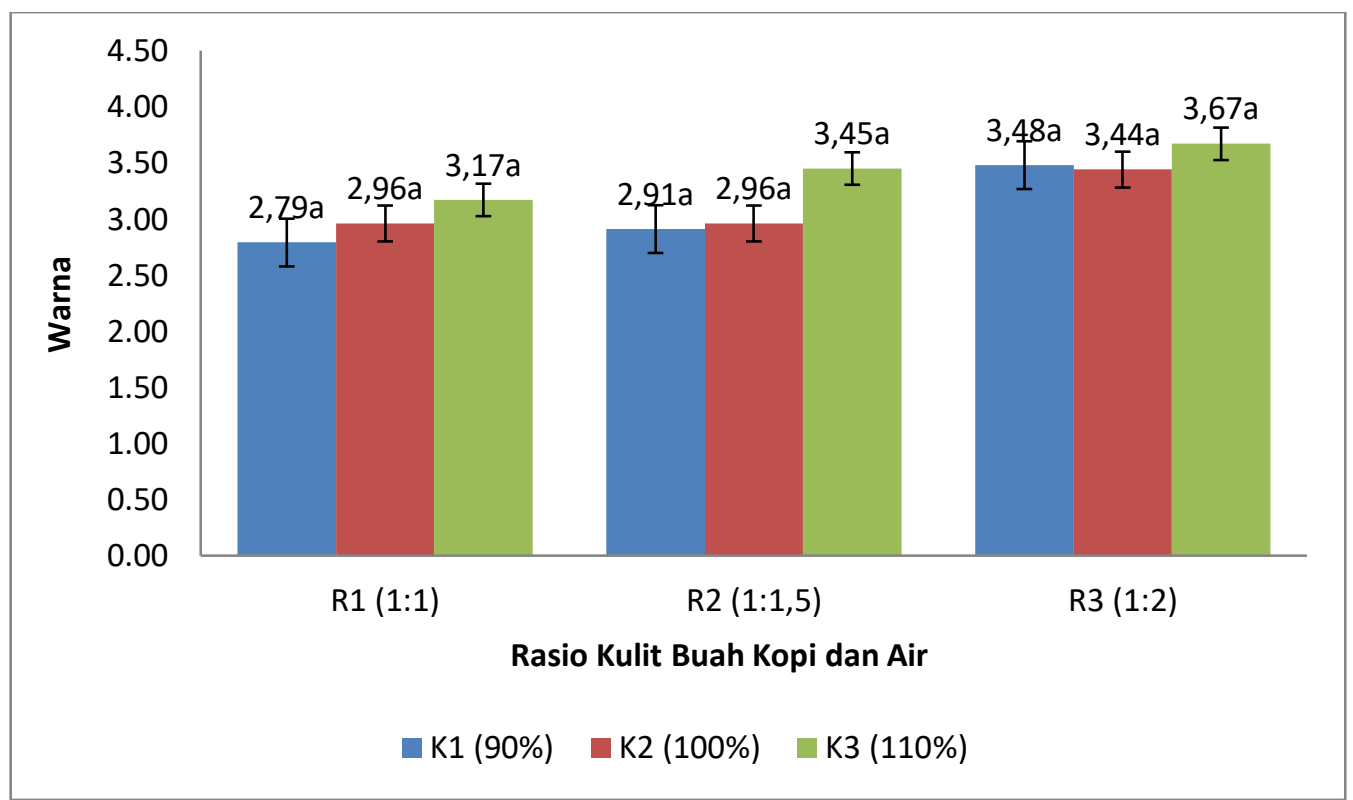

Gambar 3. Pengaruh interaksi antara rasio kulit buah kopi dan air serta konsentrasi gula terhadap warna sirup kulit buah kopi $\left(\right.$ DMRT $_{0,01}$ taraf1 $=8,49$; taraf $2=6,20$; taraf $3=5,27$; taraf $4=4,75$; taraf $5=$ 4,42 ; taraf $6=4,18 ; \operatorname{taraf} 7=4,01 ; \operatorname{taraf} 8=3,87$ dan taraf $9=3,76$. KK =93,23). Nilai yang diikuti huruf yang sama menunjukkan perbedaan yang tidak nyata.

Berdasarkan uji lanjut DMRT pada Gambar 3, dapat dilihat bahwa nilai organoleptik warna dari sirup kulit buah kopi dengan perlakuan interaksi rasio kulit buah kopi dan konsentrasi gula yang berbeda memiliki nilai yang sama atau tidak berbeda nyata, yang ditunjukkan dengan huruf notasi yang sama. Hal ini menunjukkan bahwa interaksi perlakuan 
rasio kulit buah kopi dan air, serta konsentrasi gula yang ditambahkan belum menunjukkan perbedaan yang nyata terhadap warna dari sirup buah kopi.

Menurut Fitriani dan Sribudiani (2009), didalam pembuatan sirup nanas selain bahan baku daging buah nanas dan kulit buah nanas, bahan tambahan seperti gula dan pengawet dalam pembuatan sirup nanas diduga dapat mempengaruhi warna sirup yang dihasilkan, sehingga sirup mengalami perubahan warna yang dapat mepengaruhi penilaian organioleptik panelis. Selain itu pengaruh pemasakan atau pemanasan dapat menyebabkan terjadinya karamelisasi gula sehingga mempengaruhi warna dari sirup. Winarno (1997), menambahkan bahwa bahan pengawet selain berfungsi mengawetkan sirup juga sebagai penegas warna, citarasa dan tekstur sehingga dapat diterima oleh panelis.

\section{Aroma}

Berdasarkan hasil penelitian, nilai organoleptik aroma sirup kulit buah kopi berkisar antara 2,44-3,32 (tidak suka - netral). Hasil sidik ragam menunjukkan bahwa rasio kulit buah kopi dan air $(\mathrm{R})$ berpengaruh sangat nyata $(\mathrm{P}>0,01)$ terhadap aroma sirup kulit buah kopi. Sedangkan konsentrasi gula $(\mathrm{K})$ dan interaksi rasio kulit buah kopi dan air serta konsentrasi gula $(\mathrm{RK})$ berpengaruh tidak nyata $(\mathrm{P}>0,05)$ terhadap aroma sirup kulit buah kopi. Pengaruh rasio kulit buah kopi dan air terhadap aroma sirup kulit buah kopi dapat dilihat pada Gambar 4.

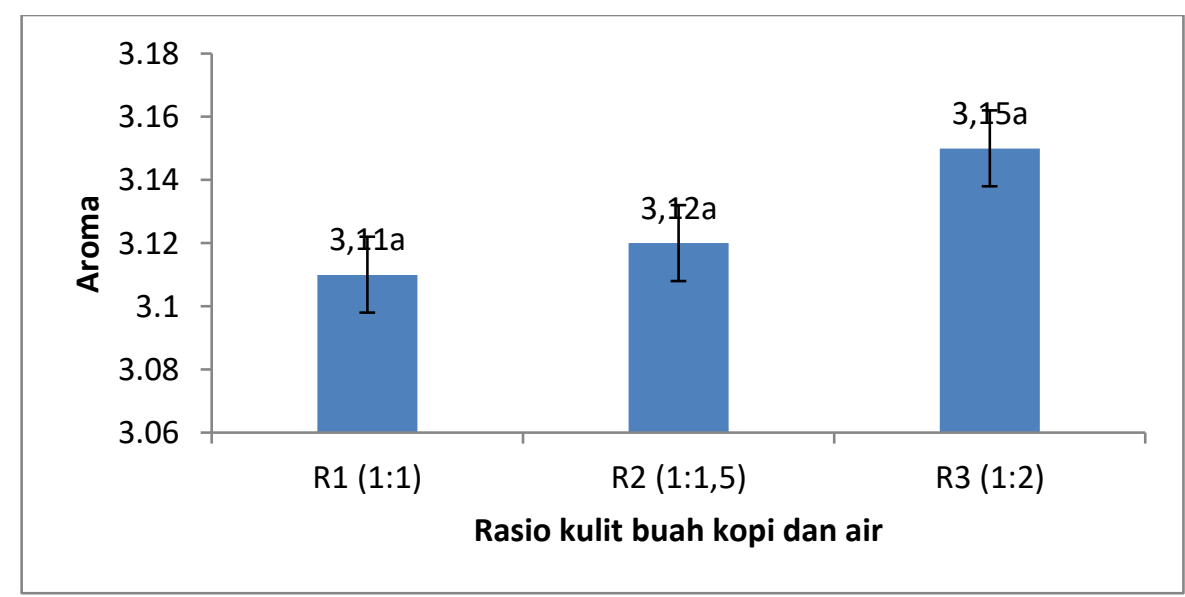

Gambar 4. Pengaruh rasio kulit buah kopi dan air terhadap aroma sirup kulit buah kopi (DMRT 0,05 taraf $1=8,57$ ; taraf $2=6,93$ dan taraf $3=6,19$. KK = 183,27\%). Nilai yang diikuti huruf yang sama menunjukkan perbedaan tidak nyata.

Berdasarkan uji lanjut DMRT pada Gambar 4, dapat dilihat bahwa nilai organoleptik aroma dari sirup kulit buah kopi dengan rasio kulit buah kopi dan air yang berbeda adalah sama atau tidak berbeda nyata, yang ditunjukkan dengan huruf notasi yang sama. Hal ini menunjukkan bahwa konsentrasi gula yang ditambahkan belum menunjukkan perbedaan yang nyata terhadap aroma dari sirup buah kopi. Hal ini diduga karena proses pemanasan pada pembuatan sirup kulit buah kopi mempengaruhi aroma sirup yang dihasilkan. Susanti (2016) mengatakan bahwa faktor-faktor yang mempengaruhi penilaian panelis seperti adanya aroma lain di sekitar tempat pengujian. Kesalahan penilaian juga dapat disebabkan karena perbedaan sensitivitas indera penciuman panelis yang berbeda-beda 


\section{Rasa}

Dari hasil penelitian diperoleh nilai organoleptik rasa dari sirup kulit kopi yaitu berkisar antara 3,16-3,63 (netral). Hasil sidik ragam menunjukkan bahwa rasio kulit kopi dan air $(\mathrm{R})$, konsentrasi gula $(\mathrm{K})$ dan interaksi keduanya $(\mathrm{RK})$ tidak berpengaruh nyata $(\mathrm{P}<0.05)$ terhadap rasa sirup kulit buah kopi. Hal ini diduga karena konsentrasi gula yang digunakan belum sesuai dengan jumlah kulit buah kopi yang digunakan sehingga rasa sepat pada kulit buah kopi belum hilang. Menurut Bastanta dkk (2017), penambahan gula pada bahan pangan bukan hanya sebagai pencipta rasa manis, melainkan juga rasa asam dan citarasa dari bahan.

\section{Kekentalan}

Dari hasil penelitian diperoleh nilai organoleptik kekentalan dari sirup kulit kopi yaitu berkisar antara 2,68 - 3,72 (tidak suka - netral). Hasil sidik ragam menunjukkan rasio kulit buah kopi dan air (R), konsentrasi gula $(\mathrm{K})$ dan interaksi rasio kulit buah kopi dan air serta konsentrasi gula $(\mathrm{RK})$ tidak berpengaruh nyata $(\mathrm{P}<0.05)$ terhadap rasa sirup kulit buah kopi. Hal ini diduga karena konsentrasi gula yang berbeda-beda menyebabkan perbedaan kekentalan pada sirup kulit buah kopi sehingga mempengaruhi penilaian panelis. Hal ini sesuai dengan pernyataan Winarno (1997) bahwa peningkatan viskositas dipengaruhi oleh adanya gula yang ditambahkan. Konsentrasi gula yang tinggi mengandung derajat brix yang tinggi sehingga meningkatkan viskositas disebabkan adanya padatan yang dapat mengikat air, sukrosa dan asam sitrat sehingga memerangkap air untuk membentuk gel.

\section{Aktivitas Antioksidan}

Pada penelitian ini analisis antioksidan dilakukan dengan menggunakan metode DPPH. Analisis antioksidan hanya dilakukan pada 3 (tiga) sampel dari perlakuan terbaik yang dipilih dengan metode ranking. Tiga sampel dari perlakuan terbaik tersebut ialah rasio kulit buah kopi dan air 1:1 serta konsentrasi gula 110\% (R1K3), rasio kulit buah kopi dan air 1:2 serta konsentrasi gula 100\% (R3K2) dan rasio kulit buah kopi dan air 1:2 serta konsentrasi gula 110\% (R3K3. Aktivitas antioksidan masing-masing perlakuan dapat dilihat pada Tabel 1.

Tabel 1. Aktivitas antioksidan sirup kulit buah kopi

\begin{tabular}{ll}
\hline Perlakuan & Antioksidan $(\%)$ \\
\hline R1K3 & 0,3125 \\
R3K2 & 0,3086 \\
R3K3 & 0,3212 \\
\hline
\end{tabular}

Berdasarkan Tabel 1, nilai aktivitas antioksidan pada perlakuan R3K3 (0,3212\%) lebih tinggi dibandingkan dengan R1K3 $(0,3125 \%)$ dan R3K2 $(0,3086 \%)$. Menurut Rifkowaty (2018), aktivitas antioksidan pada sirup buah karamunting dengan perlakuan penambahan asam sitrat $0 \%, 0,05 \%$ dan $0,01 \%$ berturut-turut ialah $43,87 \%, 81,99 \%$ dan $86,47 \%$. Yuliana dkk (2017) menjelaskan bahwa jumlah antioksidan yang kecil pada sirup buah mengkudu dapat disebabkan oleh penambahan air karena semakin tinggi pengenceran senyawa antioksidan menyebabkan aktivitas antioksidan berkurang. Selain itu, proses pemanasan juga mempengaruhi antioksidan yang terkandung dalam sirup buah. 


\section{KESIMPULAN DAN SARAN}

Konsentrasi gula $(\mathrm{K})$ berpengaruh sangat nyata $(\mathrm{P}>0,01)$ terhadap $\mathrm{pH}$ sirup kulit buah kopi. Perlakuan rasio kulit buah kopi dan air (R) dan konsentrasi gula (K) tidak berpengaruh nyata terhadap nilai total asam sirup kulit kopi, sedangkan interaksi rasio kulit buah kopi dan air serta konsentrasi gula $(\mathrm{RK})$ berpengaruh nyata $(\mathrm{P}>0,05)$ terhadap total asam sirup kulit kopi. Interaksi antara rasio kulit buah kopi dan air $(\mathrm{RK})$ berpengaruh sangat nyata $(\mathrm{P}>0,01)$ terhadap nilai organoleptik warna dan aroma sirup kulit buah kopi. Perlakuan rasio kulit buah kopi dan air $(\mathrm{R})$ berpengaruh nyata $(\mathrm{P}>0,05)$ terhadap nilai organoleptik aroma sirup kulit buah kopi. Namun perlu dilakukan penelitian lebih lanjut mengenai sirup kulit buah kopi dengan bahan baku dengan kematangan berbeda untuk menghasilkan viskositas sirup yang lebih baik.

\section{DAFTAR PUSTAKA}

Bastanta, D., T. K. Karo dan H. Rusmarilin. 2017. Pengaruh Perbandingan Sari Sirsak dengan Sari Bit dan Konsentrasi Gula terhadap Sirup Sabit. Jurnal Rekayasa Pangan dan Pertanian, Vol. 5, No. 1.

Bawinto, A. S., E. Mongi dan B. E. Kaseger. 2015. Analisa Kadar Air, Organoleptik dan Kapang Pada Produk Ikan Tuna (Thunnus sp.) Asap di Kelurahan Girian Bawah, Kota Bitung, Sulawesi Utara. Jurnal Media Teknologi Hasil Perikanan, Vol. 3., No. 2.

Fitriani, S dan Sribudiani. 2009. Pengembangan Formulasi Sirup Berbahan Baku Kulit dan Buah Nanas (Ananas comosus L. Merr). Jurnal Sagu, Vol. 8, No. 1.

Hanani E, A. Mun'im , R. Sekarini. 2005. Identifikasi Senyawa Antioksidan dalam Spons Callispongia sp dari Kepulauan Seribu. Majalah Ilmu Kefarmasian.

Rifkowaty, E. E., A. P.Wardanu dan N.D.Hastuti. 2018. Aktivitas Antioksidan Sirup Buah Karamunting (Rhodomyrtus tomentosa) dengan Penambahan Asam Sitrat. Jurnal Teknologi dan Industri Pertanian, Vol. 8, No. 1.

Sihombing, E. S. 2013. Kualitas Sirup Jambu Biji Merah (Psidium guajava L.). Skripsi. Fakultas Pertanian Universitas Riau, Pekan Baru.

Simanihuruk, K dan J. Sirait. 2010. Silase Kulit Buah Kopi Sebagai Pakan Dasar pada Kambing Boerka Sedang Tumbuh. Loka Penelitian Kambing Potong, Sumatera Utara. PT. Balai Pustaka, Jakarta.

Susanti, C. 2016. Pengaruh Perbandingan Sari Buah Naga Merah (Hylocereus poyrhyzus) dengan Sari Buah Salak Bongkok (Salacca edulis Reinw) dan Jenis Penstabil Terhadap Karakteristik Sirup Buah. Jurusan Teknologi Pangan Fakultas teknik Universitas Pasundan, Bandung.

Tarigan, E. B., D. Pranowo dan T. Iflah. 2015. Tingkat Kesukaan Konsumen Terhadap Kopi Campuran Robusta dengan Arabika. Jurnal Teknologi dan Industri Pertanian Indonesia, Vol. 7, No. 1.

Tarwendah, I. P. 2017. Studi Komparasi Atribut Sensoris dan Kesadaran Merek Produk Pangan. Jurnal Pangan dan Agroindustri, Vol. 5, No. 2.

Widyotomo, S. 2012. Potensi dan Teknologi Diversifikasi Limbah Kopi Menjadi Produk Bermutu dan Bernilai Tambah. Pusat Penelitian Kopi dan Kakao Indonesia, Jember.

Winarno, F. G. 1997. Kimia Pangan dan Gizi. Gramedia, Jakarta.

Yuliana, R., S. I. Rahmawati dan N. Novidahlia. 2017. Minuman Sirup Limbah Sari Mengkudu (Molinda citrifolia L). Jurnal Pertanian, Vol. 8, No. 2. 
Zulkarnain, A. K., M. Susanti dan A. N. Lathifa. 2013. Stabilitas Fisik Sediaan Lotion $O / W$ dan W/O Ekstrak Buah Mahkota Dewa Sebagai Tabir Surya dan Uji Iritasi. Jurnal Trad. Med., Vol. 18, No. 3. 